\title{
ПИТАННЯ ПІДГОТОВКИ ДОКТОРІВ ФІЛОСОФІї ЗА СПЕЦІАЛЬНІСТЮ
} 223 «МЕДСЕСТРИНСТВО»

Питання підготовки докторів фрілософрії за спеціальністю 223 «Медсестринство»

\section{М. І. Марущак, І. М. Кліщ}

Тернопільський національний медичний університет імені І. Я. Горбачевського МОЗ України

Резюме. В усьому світі підготовку медичних сестер на третьому рівні вищої освіти було визначено як основний фрактор при проведенні реалістичних досліджень, керівництві, розробці політики та освітній підготовці в галузі медсестринства.

Мета дослідження - висвітлити ряд думок учасників круглого столу щодо питань удосконалення підготовки орахівців третього рівня вищої освіти за спеціальністю 223 «Медсестринство», що реалізується в Тернопільському національному медичному університеті імені І. Я. Горбачевського МОЗ України.

Матеріали і методи. Було запрошено 6 провідних фрахівців (зовнішніх стейкголдерів) за спеціальністю 223 «Медсестринство» для обговорення иляхів удосконалення підготовки докторів фрілософрії за спеціальністю 223 «Медсестринство» в Тернопільському національному медичному університеті імені І. Я. Горбачевського МОЗ України.

Результати. Щодо освітньо-наукової програми третього рівня вищої освіти (кваліфрікація доктор фрілософріі) зовнішні стейкголдери під час круглого столу відмітили, що ії розробили на основі синтезу кращих практик шкіл медсестринства України та зарубіжжя. Зовнішні стейкголдери рекомендували готувати багатопрофрільну $\mathrm{PhD}$ медсестру через можливість вибору вибіркових дисциплін, а не звужувати освітню програму до вузького профрілю. Також були обговорені пріоритетні наукові напрямки, які засвідчили необхідність проведення наукових досліджень, пов'язаних із реалізацією освітніх складових, а не лише тих, що стосуються практичної діяльності медсестри. Важливим питанням, яке підняли фрахівці з медсестринства під час круглого столу, було питання фрункціональних обов'язків медичної сестри, доктора фрілософрії.

Висновки. На даний час Україна перебуває на початковому етапі підготовки докторів фрілософрії із медсестринства, проте освітньо-наукова програма, за якою навчаються здобувачі в Тернопільському національному медичному університеті імені І. Я. Горбачевського МОЗ України за спеціальністю 223 «Медсестринство» (третій рівень вищої освіти) є синтезом кращих практик шкіл медсестринства України та зарубіжжя, що дозволяє сформувати медичних сестер - лідерів у напрямках науки, освіти та практичної діяльності, здатних виховати наступне покоління медсестер.
Questions of training doctors of philosophy in the specialty 223 "Nursing"

M. I. Marushchak, I. M. Klishch

I. Horbachevsky Ternopil National Medical University e-mail: marushchak@tdmu.edu.ua

Summary. Worldwide, the training of third-level nurses in higher education has been identified as a major factor in realistic research, leadership, policy development and nursing education.

The aim of the study - to highlight a number of views of the round table on improving the training program of third-level higher education in the specialty 223 "Nursing", which is implemented at I. Horbachevsky Ternopil National Medical University, Ukraine.

Materials and Methods. 6 leading specialists (external stakeholders) in the specialty 223 "Nursing" were invited to discuss ways to improve the training program of doctors of philosophy in the specialty 223 "Nursing" at I. Horbachevsky Ternopil National Medical University.

Results. Regarding the educational and scientific program of the third level of higher education (qualification of Doctor of Philosophy) by external stakeholders during the round table it was noted that it was developed on the basis of synthesis of best practices of nursing schools in Ukraine and abroad. External stakeholders recommended training a multidisciplinary PhD nurse because of the choice of elective courses, rather than narrowing the curriculum to a narrow profile. Priority areas of research were also discussed, which highlighted the need for research related to the implementation of educational components, and not only those related to the practice of nursing. An important issue raised by the nurses during the roundtable was the functional responsibilities of the nurse, $P h D$.

Conclusions. At present, Ukraine is at the initial stage of training doctors of philosophy in nursing, but the educational and scientific program, which is studied by applicants at I. Horbachevsky Ternopil National Medical University in specialty 223 "Nursing" (3rd level of higher education) is a synthesis of the best practices of nursing schools in Ukraine and abroad and allows to form nurses - leaders in science, education and practice, able to educate the next generation of nurses. 
Ключові слова: медсестра; доктор фрілософії; підготовка; освітньо-наукова програма.

\section{ВСТУП}

У всьому світі підготовку медичних сестер на третьому рівні вищої освіти було визначено як основний фрактор у проведенні реалістичних досліджень, керівництві, розробці політики та освітній підготовці в галузі медсестринства [1]. Докторська сестринська освіта визнана ключовою у розвитку наукових лідерів у сфері медсестринської практики, управління, досліджень, політики, освіти та навчання. Крім того, підготовка медичних сестер на третьому рівні вищої освіти є незамінною для багатовимірного та трансформаційного процесу особистісного та профресійного зростання медичних сестер [2, 3]. У глобальному масштабі було зрозуміло, що зростання здібностей медсестринського персоналу є важливою стратегією для досягнення цілей сталого розвитку та зміцнення системи охорони здоров'я.

В Україні досить недавно впроваджено ступеневу підготовку медичних сестер, зокрема третій освітньо-науковий рівень вищої освіти, що дозволить удосконалити підготовку ліцензованих медичних сестер і підвищити якість надання медсестринських послуг, запроваджений з 2017 р.

У свою чергу, в Сполучених Штатах Америки (США) вчений ступінь доктора фрілософрії (PhD) 3 медсестринства, найвищий рівень освіти, який може отримати медсестра, бере свій початок 3 XX ст. Докторську освіту для медсестер було розпочато в педагогічному коледжі Колумбійського університету в 1933 р. та в Нью-Йоркському університеті в 1934 р. [4]. При цьому вчені пов'язують таку затримку 3 унікальною історією медсестер серед профресій, оскільки медсестринство в США починалося поза межами основної вищої освіти і було майже виключно в лікарнях. Ці лікарні, а також пізніше університети, куди перейшли освітні програми для медсестер, контролювалися адміністративними структурами, які найкраще описати як дуже патерналістські. Ці патерналістські організації, у поєднанні $з$ тим фрактом, що більшість медсестер були і залишаються жінками, можливо, затримали професію від прийняття докторських ступенів як необхідного сертифіката для професійного лідерства [5].

Освітньо-наукова програма третього рівня вищої освіти - це науково-дослідний ступінь, який готує медсестер, які проводять важливі медичні дослідження, що сприятимуть розвитку всієї сорери медсестринства, а також для викладання медсестринства в освітніх закладах. Для вступу на PhDпрограми в США медсестри попередньо повинні отримати ступінь бакалавра медсестер (BSN)
Key words: nurse; doctor of philosophy; training; educational and scientific program.

та скласти іспит NCLEX-RN. У деяких випадках здобувачі PhD повинні спочатку отримати ступінь магістра медсестер (MSN), яка надає передову освіту 3 медсестринської практики 3 курсами із фрармакології, клінічної патофрізіології та клінічної практики [6].

Метою дослідження було висвітлити ряд думок учасників круглого столу щодо питань удосконалення підготовки фрахівців третього рівня вищої освіти за спеціальністю 223 «Медсестринство», що реалізується в Тернопільському національному медичному університеті імені І. Я. Горбачевського МОЗ України.

\section{МАТЕРІАЛИ I МЕТОДИ}

Було запрошено 6 провідних фрахівців (зовнішніх стейкголдерів) за спеціальністю 223 «Медсестринство» для обговорення шляхів удосконалення підготовки докторів фрілософії за спеціальністю 223 «Медсестринство» в Тернопільському національному медичному університеті імені І. Я. Горбачевського МОЗ України.

\section{РЕЗУЛЬТАТИ Й ОБГОВОРЕННЯ}

Щодо освітньо-наукової програми третього рівня вищої освіти (кваліфрікація доктор фрілософрії) зовнішні стейкголдери під час круглого столу відмітили, що її розробили на основі синтезу кращих практик шкіл медсестринства України та зарубіжжя, що дозволяє ідентифікувати медичних сестер як перспективних вчених та лідерів у своєму напрямку, здатних виховати наступне покоління медсестер. Підготовка таких фрахівців є надзвичайно необхідною для вітчизняної галузі охорони здоров'я, тому першочерговим завданням учасники круглого столу вважають необхідність зробити привабливим здобуття доктора фрілософрії за спеціальністю «Медсестринство» [7].

Серед основних мотивацій до навчання на PhDпрограмі за спеціальністю «Медсестринство»в США $є$ можливість вплинути на більш високому рівні на політику чи сорормувати наступне покоління медсестер, здобувши ступінь доктора фрілософрії в галузі «Медсестринство». Університет Валдена закликає: «Знайдіть свій голос і набудьте впевненості, яка вам потрібна, щоб втілити свої знання, досвід та ідеї в дію» [8]. Варто зазначити, що цей університет вже 50 років готує докторів фрілософії із медсестринства.

Зовнішні стейкголдери рекомендували готувати багатопрофрільну PhD-медсестру через можливість вибору вибіркових дисциплін, а не звужувати освітню програму до вузького профілю. Також 
були обговорені пріоритетні наукові напрямки, які засвідчили необхідність проведення наукових досліджень, пов'язаних із реалізацією освітніх складових, а не лише тих, що стосуються практичної діяльності медсестри.

Дослідження, проведене в Індії, показало, що їхні програми підготовки докторів фрілософрії 3 медсестринства в основному зосереджені на біомедичних або психосоціальних дисциплінах, а не лише пов'язані з медсестринством. Автори зазначають, що докторська сестринська освіта має бути зосереджена на розвитку науки та сукупності знань для медсестринства, а теми наукових робіт повинні бути зосереджені на сестринській науці, як-от дослідження із забезпечення якості медсестринської практики, освіти та адміністрування, розробка та тестування теорій/моделей медсестри, розробка інструментів для вимірювання френомену сестринського догляду, дослідження, які можуть вплинути на політику, пов'язану з сестринською практикою, освіту та адміністрування тощо [9]. Освітньо-наукова програма доктора фрілософії з медсестринства має бути сорормована таким чином, щоб дозволити медичним сестрам зайняти позиції лідерів у різноманітних системах охорони здоров'я та освіти.

Однією із загроз якості докторської медсестринської освіти є відсутність нормативно-правових актів та акредитації освітніх програм в університетах, що надають такі освітні послуги. На даний момент, завдяки потужній роботі Національного агентства забезпечення якості вищої освіти, в Україні була акредитована одна освітньо-наукова програма. Освітньо-наукова програма нашого університету також перебуває в акредитаційному процесі. Крім того, директорка державної установи «Центр розвитку медсестринства Міністерства охорони здоров'я України» зазначила, що на даний час готується стандарт підготовки медичних сестер на третьому рівні вищої освіти, де будуть зазначені основні вимоги до таких фрахівців.

Варто також відмітити, що в США є близько 130 освітньо-наукових програм, орієнтованих на підготовку докторів фрілософії за спеціальністю медсестринство, та понад 330 освітніх програм в 34 країнах світу, тоді як в Україні є лише 2 [10].

Важливим питанням, яке підняли фрахівці з медсестринства під час круглого столу було питання функціональних обов'язків медичної сестри, доктора фрілософії. Учасники круглого столу зазначили, що повсякденні обов'язки медичних сестер будуть відрізнятися залежно від того, який кар'єрний напрямок вони обрали: дослідницький, освітній напрямки чи практичну діяльність. Проте на даний час функціональні обов'язки медичної сестри, доктора фрілософії, перебувають на стадії обговорення.

До типових обов'язків медсестри, доктора фрілософрії, у країнах Європи та США входять: планування та проводення наукових досліджень самостійно або у партнерстві 3 іншими вченими з різних галузей; збір та аналіз наукових даних; публікація результатів дослідження, подача заявок на гранти та фрінансування досліджень, створення та підтримка програм забезпечення якості, достовірності результатів досліджень, навчання та контроль роботи персоналу, планування, моніторинг та оновлення навчального плану та навчальних матеріалів для курсів медсестер, читання лекцій для студентів медсестер, керівник наукової та клінічної роботи студентів, консультування студентів щодо їхньої майбутньої роботи в галузі медсестринства.

\section{ВИСНОВКИ}

Підсумовуючи результати зустрічі, показано, що наразі Україна на початковому етапі підготовки докторів фрілософрії із медсестринства, проте освітньо-наукова програма, за якою навчаються здобувачі в Тернопільському національному медичному університеті імені І. Я. Горбачевського МОЗ України за спеціальністю 223 «Медсестринство» (третій рівень вищої освіти) є синтезом кращих практик шкіл медсестринства України та зарубіжжя і дозволяє сорормувати медичних сестер - лідерів у напрямках науки, освіти та практичної діяльності, здатних виховати наступне покоління медсестер.

\section{СПИСОК ЛІТЕРАТУРИ}

1. Issues and challenges in international doctoral education in nursing / S. Ketefian, P. Davidson, J. Daly [et al.] // Nurs. Health Sciences. - 2005. - No. 7 (3). - P. 150-156.

2. Lee C. J. The experience of nurse faculty members enrolled in doctoral study / C. J. Lee // International Journal of Doctoral Studies. - 2009. - No. 9. - P. 59-75.

3. Особливості підготовки здобувачів третього освітнього-наукового рівня за спеціальністю 223«Медсестринство» / М. І. Марущак, Л. П. Мазур, І. Я. Криницька, І. М. Кліщ // Вісник медичних і біологічних досліджень. 2021. - № 3 (9). - С. 54-57.

4. Evolution and current scenario of doctoral nursing education in India / S. K. Sharma, R. Rani, S. Banerjee [et al.] //
Journal of Medical Evidence. - 2021. - No. 2 (1). P. $79-85$.

5. DeNisco S. M. Advanced practice nursing: Evolving roles for the transformation of the profession/ S. M. DeNisco, A. M. Barker // Nursing Faculty Publications. - 2013. No. 19.

6. Getting Your Ph.D. in Nursing: https://www. registerednursing.org/phd.

7. Марущак М.І. Задоволення профресійною діяльністю як показник самореалізації медичних сестер / М. І. Марущак, Х. Я. Максів // Вісник медичних і біологічних досліджень. - 2021. - № 3 (9). C. $58-64$. 
8. Earn your PhD in Nursing from the leader in graduate nursing education: https://www.waldenu.edu/onlinedoctoral-programs/phd-in-nursing.

9. McKenna H. P. Doctoral education in nursing:

\section{REFERENCES}

1 Ketefian S, Davidson P, Daly J. Issues and challenges in international doctoral education in nursing. Nurs Health Sciences. 2005;7(3): 150-6. doi.org/10.1111/j.14422018.2005.00240.x

2. Carolyn JL. The experience of nurse faculty members enrolled in doctoral study. International Journal of Doctoral Studies. 2009;9: 59-75. doi.org/10.28945/45

3. Marushchak M, Mazur L, Krynytska I, Klishch I. Features of training of applicants of the third educational and scientific level of specialty 223 "Nursing". Visn med i boil nauk. 2021;3(9): 54-7. doi.org/ 10.11603 /bmbr. 27066290 . 2021.3.12570. Ukrainian.

4. Sharma SK, Rani R, Banerjee S. Evolution and current scenario of doctoral nursing education in India. Journal of Medical Evidence. 2021;2(1): 79-85.

5. DeNisco SM, Barker AM. Advanced Practice Nursing:
International perspective / H. P. McKenna, S. Ketefian // Oxford: Routledge. - 2004. - P. 144-158.

10. Coetzee S. K. The quality of doctoral nursing education in South Africa / S. K. Coetzee, H. C. Klopper, M. J. Kim // Curationis. - 2015. - No. 38 (1). - P. 1-9.

Evolving Roles for the Transformation of the Profession. Nursing faculty publications. 2013;19.

6. Getting Your Ph.D. in Nursing: https://www. registerednursing.org/phd.

7. Marushchak M, Maksiv H. Satisfaction with professional activity as an indicator of self-realization of nurses. BMBR. 2021;3(9): 58-64. doi.org/10.11603/ bmbr.2706-6290.2021.3.12571

8. Earn your PhD in Nursing from the leader in graduate nursing education: https://www.waldenu.edu/onlinedoctoral-programs/phd-in-nursing

9. McKenna HP, Ketefian S. Doctoral education in nursing: International perspective. Oxford: Routledge. 2004: 144-58.

10. Coetzee SK, Klopper HC, Kim MJ. The quality of doctoral nursing education in South Africa. Curationis. 2015;38(1): 1-9. 